\title{
REMOVAL OF OIL AND GREASE AS EMERGING POLLUTANTS OF CONCERN (EPC) IN WASTEWATER STREAM
}

\author{
Abass O. Alade, Ahmad T. Jameel, Suleyman A. Muyubi, \\ MOHAMEd I. AbDUl Karim AND MD. Zahangir AlaM \\ Bioenvironmental Engineering Research Unit, \\ Biotechnology Engineering Department, Kulliyyah of Engineering, \\ International Islamic University Malaysia, \\ Jalan Gombak, 53100, Kuala Lumpur, Malaysia. \\ abasslad@yahoo.com
}

\begin{abstract}
Wastewater characteristics, which depend on wastewater source, are increasingly becoming more toxic in recent times. The concentrations of oil and grease in wastewater streams have been observed to increase in wastewater stream with increasing adverse effects on the ecology. This results from the increasing use of oil and grease in high-demanded oil-processed foods, establishment and expansion of oil mills and refineries worldwide, as well as indiscriminate discharge of oil and grease into the water drains, domestically and industrially. This study reports the applications, efficiencies and challenges of the wastewater treatment techniques currently employed in the removal of oil and grease from the industrial wastewater and municipal water stream. The results shows that the concentrations of oil and grease injected into the ecosystem are of higher environmental impact and this needs to be given the desired attention. The desired development for effective removal of oil and grease as emerging pollutants of concern (EPC) in wastewater stream are thus proposed.
\end{abstract}

ABSTRAK: Ciri-ciri air sisa, bergantung kepada punca air sisa tersebut, menjadi semakin toksik akhir-akhir ini. Kepekatan minyak dan gris dalam air sisa anak sungai dilihat makin bertambah dalam air sisa anak sungai dengan bertambahnya kesan negatif ke atas ekologi. Ini disebabkan oleh peningkatan penggunaan minyak dan gris dalam makanan berproses yang tinggi permintaannya, penubuhan dan perkembangan kilang pertroleum dan loji penapisan di seluruh dunia. Minyak dan gris juga dibuang sewenangwenangnya ke dalam parit air, dari kalangan domestik dan industry. Kajian ini membentangkan tentang aplikasi, keberkesanan dan teknik cabaran rawatan air buangan yang kini digunakan dalam pembuangan minyak dan gris dari air sisa industry dan air sungai perbandaran. Keputusan menunjukkan kepekatan minyak dan gris yang wujud dibuang ke dalam ekosistem mempunyai impak yang lebih tinggi terhadap persekitaran dan hal ini perlu diambil berat. Keinginan untuk kemajuan penyingkiran minyak dan gris sebagai keprihatinan terhadap pencemaran (emerging pollutants of concern $(E P C))$ ke atas air sisa sungai dicadangkan.

KEYWORDS: emerging pollutants of concern (EPC); oil; grease; wastewater

\section{INTRODUCTION}

Oil contaminated wastewater comes from variety of sources such as crude oil production, oil refinery, petrochemical industry, metal processing, compressor condensates, lubricant and cooling agents, car washing, restaurants [1]. Oily wastewater contains toxic substances such as phenols, petroleum hydrocarbons, polyaromatic 
hydrocarbons, which are inhibitory to plant and animal growth, equally, mutagenic and carcinogenic to human being. Similarly, oily wastewater contains high oil content, chemical oxygen demand (COD) and colour [1]. The increase in global demand for edible oils has in the last few decades has resulted in a tremendous increase in the cultivation of oil seeds, particularly of soybean and oil palm [2]. The oil seeds are usually processed to obtain the oil contents which are subsequently processed for human consumption and industrial applications. Thus the vegetable oil industries are, equally, associated with oil extraction, refining, transportation, uses and reuses. However, these industries have been linked with environmental pollutions resulting from oil spill, oily effluent discharge into water bodies and oily sludge discharge into the environment indiscriminately, untreated or in conditions below the standard discharge limits. Oil and grease containing wastes generated from vegetable oil origin are generally classified as serious types of hazardous pollutants particularly when injected into the aquatic environments where they pose high toxicity to the aquatic organisms and other ecology damages to the water bodies [3].

Oil and grease is defined as a group of related materials rather than a specific chemical compound extractable by certain solvents, such as hexane $[4,5]$. They are nonpolar and, as a result, are hydrophobic in nature [5]. Generally, oil is not soluble in the water-phase and the nature of the oil-phase in oily wastewater is different from one case to another $[6,7]$. Under anaerobic conditions, oils and grease hydrolyze to long chain fatty acids (LCFA) and glycerol [8, 9]. The glycerol further degrades to 1, 3-propanediol [10] and subsequently to acetate [11]. Oil-water mixture with droplets greater than or equal $(\geq)$ to 150 microns is classified as free oil while oil-water mixture with droplets size ranging between 20 and 150 microns, are classified as dispersed oil mixture. Emulsified oil mixture are oil-water mixture with droplet sizes smaller than 20 microns and oil-water mixture with droplet sizes smaller than 5 microns are classified as soluble oil mixture [12].

This study focuses on wastewater containing oil and grease resulting from the extraction, refining, transportation and utilization of vegetable oil obtained from plant and animal sources except otherwise in a general form to include oil from other sources like petroleum and others.

\section{VEGETABLE OIL SOURCES}

The consumption of vegetable oil increased $(3.5 \%)$ rapidly nearly twice more than the world population increased (1.6\%) between 1980 and 2000. Predominant oil-bearing crops sourced for the production of vegetable oil include Soybean, palm, sunflower, safflower, cottonseed, rapeseed, and peanut. World major exporters of vegetable oils include Malaysia, Argentina, Indonesia, the Philippines, and Brazil while countries such as the Netherlands, Germany, the United States, and Singapore are both major exporters as well as importers of vegetable oils [13]. Countries such as China, Pakistan, Italy, and the United Kingdom are the leading world major importers of vegetable oils. Vegetable oils are generally obtained through extraction and refining processes of oils and fats from vegetable and animal sources. The initial crude oil obtained usually contains free fatty acids, phospholipids, sterols, water, odorants, and other impurities. Furthermore, refined oils and fats contain small amounts of free fatty acids and water [14]. Preliminary preparation of vegetable oil raw materials includes husking, cleaning, crushing, and conditioning after which the oil is extracted through mechanically pressing or using solvents such as hexane. The oil are carefully recovered from the extraction process through is skimming, filtration, and distillation depending on the method of extraction while the refining processes includes degumming, neutralization, bleaching, 
deodorization, and advanced refining process for specific demand from industries such as pharmaceutical [15].

\section{SOURCES OF OIL AND GREASE IN WASTEWATER}

The largest source of wastewater is produced during oil extraction processes in most oil mills and the mill effluents such as palm oil mill effluent POME may be categorized as an oily wastewater due to its high concentrations (4000 to $6000 \mathrm{mg} / \mathrm{l}$ ) of oil and grease [16]. The concentration of oil and grease in an untreated domestic wastewater is always in the range between 50 to $100 \mathrm{mg} / \mathrm{l}$ [17]. Kitchen greywater is reported as the highest contributor of oil and grease in domestic greywater, though oil and grease is present in all greywater streams [18]. The presence of oil and grease has been detected in greywater, which are often designated for irrigation purposes [5, 18]. Travis et al. [5], showed that soils irrigated with greywater indicate accumulation of oil and grease up to $200 \mathrm{mg} \mathrm{kg}^{-1}$ within the first $20-\mathrm{cm}$ of depth and this consequently lead to a significant reduction in the soils ability to transmit water. Some food processing industries such as slaughterhouses, dairy and meat packing industries are well known for producing effluents containing oil and grease [19-21]. Oil containing wastewater is also sourced from non-vegetable oil manufacturing industries such as the steel, machine, petroleum refining, metal cutting and metal forming, and textile industries [7]. Oily wastewater from the metalworking and finishing industries is generated from the application of coolants and lubricants used for cooling the work pieces and machine tools, reducing friction and wear of tools and dies, as well as improving the surface quality of work pieces. Industrialized countries such as United Kingdom, Italy and Germany produced large volume of such effluent [22]. The bilge water usually contains fuel oils, lubricating oils, hydraulic oils, and detergents and their concentrations largely depend on the ship type and ship-operating mode [23]. Thus, such large of amount oily wastewater has qualified oil and grease as emerging pollutants of concern (EPC) in wastewater stream.

\section{ENVIRONMENTAL IMPACT OF OIL AND GREASE IN WASTEWATER}

World water bodies are increasingly polluted with oily water, its effects can be irreversible for aquatic living organisms, and the consequences of these effects are transferred, indirectly or directly, to humans, as they are also involve in the in the food chain of the ecosystem. The presence of oil and grease in water bodies leads to the formation of oil layer, which causes significant pollution problem such as reduction of light penetration and photosynthesis. It further hinders oxygen transfer from atmosphere to water medium and this leads to decreased amount of dissolved oxygen (DO) at the bottom of the water and this adversely affects survival of aquatic life in water [24]. Stams and Oude [25] reported the effects of oil and grease in wastewater steam to include physical blockages in sewers, pump, screens and filter distributor arms, and these consequently lead to increase maintenance costs. These effects also include accumulation of lighter oils in the wet wells of pumping stations, fouling of electrodes or float systems which leads to pump controls failures. Where the nature of oil is highly flammable, it leads to explosion hazard in the treatment works [21]. Excessive grease in the wastewater stream causes difficulties in sludge pressing because of 'blinding effect' on the filter cloths [26]. Furthermore, oil and grease interfere with aerobic biological wastewater treatment processes by reducing oxygen transfer rates. Equally, oil and grease reduce the efficacy of anaerobic treatment processes by reducing the transport of soluble substrates to the 
bacterial biomass $[27,28]$. Similarly, in the municipal water treatment plant, oil and grease cause objectionable taste and odors, turbidity and film, and make filtration treatment difficult [29].

\section{TEST METHOD FOR EXTRACTION OF OIL AND GREASE IN WASTEWATER}

The test procedures used to measure the concentrations of oil and grease in typical oily wastewater target only conglomerate of oily substances that are extractable by specific solvents. The American Public Health Association (APHA)'s Methods for the Examination of Water and Wastewater [30] suggested the use of the Partition-Gravimetric Method (503A) which involves the extraction of dissolved and emulsified oil and grease using trichlorotrifluoroethane. Other provisions are the Partition-Infrared Method (503B) which uses an extraction process identical to the 503A method together with Infrared Detection Methods and the Soxhlet Extraction Method (503C) which is based on an acidification of the sample, separating the oils from the liquid through filtration and extraction using trichlorotrifluoroethane. The Environmental Protection Agency (EPA), similarly favours 503A method under the General Pretreatment Regulations, 40 CFR 403.12(b) (5) (vi) for wastewater sampling and analyses.

A New ASTM Method D7066-04 is currently recommended as quick and easy field analysis method for determining oil and grease concentrations particularly for offshore oil platforms, soil remediation sites and industrial wastewater measurement. This development is due to the Montreal Protocol in 1995 banned on the use of Freon 113, which is widely employed in the ASTM method (D3921) for analyzing wastewater. The new ASTM Method D 7066-04, Standard Test Method for dimmer/trimmer of chlorotrifluoroethylene (S-316) under Recoverable Oil and Grease and Nonpolar Material by Infrared Determination, uses a similar extraction procedure with a more ozone friendly solvent called S-316. A variety of infrared instruments such as the full spectrum Fourier Transform Infrared (FTIR) spectrometers as well as portable and relatively inexpensive fixed filter infrared analyzers such as the Wilks InfraCal TOG/TPH Analyzer can be used with ASTM Method D7066-04. With the new ASTM method, options for onsite analysis of oil and grease have increased and thus lower laboratory costs, avoid out-of compliance fees, and improve remediation efficiency [31].

\section{DISCHARGED REGULATIONS FOR OIL AND GREASE IN WASTEWATER}

The emerging strict legislation for protection of environment demands for the application of appropriate treatment technology for the wastewater emanating from oil processing industries. The early daily allowable maximum limit for oil and grease in industrial nation such as the United State of America was $35 \mathrm{mg} / \mathrm{L}$ and the average per month was less than $17 \mathrm{mg} / \mathrm{L} \mathrm{[32].} \mathrm{Upward} \mathrm{review} \mathrm{of} \mathrm{these} \mathrm{regulations} \mathrm{shifted} \mathrm{the} \mathrm{new}$ maximum limit for daily allowable oil to $15 \mathrm{mg} / \mathrm{L}$ and the average per month is $12 \mathrm{mg} / \mathrm{L}$. The Malaysian Department of Environment (DOE) has limited the standard discharge of oil and grease, particularly in palm oil mill effluents (POME), to $50 \mathrm{mg} / \mathrm{L}$, under the current Environmental Quality Practice for the palm oil mills [33].

\section{TREATMENT PROCESSES FOR OIL AND GREASE IN WASTEWATER}


Oil and grease in the wastewater from oil processing industries are removed by various accepted techniques and the selection of the required equipment depends on the condition of the oil-water mixture. Some of the common conventional methods of oily wastewater treatment include flotation, gravitational methods, chemical treatment, biological treatment, dissolved air flotation (DAF) and use of membranes [34]. However, these methods are not efficient enough to treat the oily wastewater particularly when the oil are finely dispersed droplets and in dilute concentration, as well as inconsistent variations in the composition of the wastewater. Oil droplets of about $50 \mu \mathrm{m}$ have been removed effectively by low cost equipment such as API separators, Corrugated Plate Interceptors (CPI), and Parallel Plate Interceptors (PPI), for primary treatment of oily water [35]. Oil droplets less than $50 \mu \mathrm{m}$ size have been removed by packed beds and dissolved air flotation (DAF) [36]. De-emulsification which is effective in breaking stable emulsions using chemicals such as sulphuric acid, iron and aluminum sulphate and reducing the amount of oil in the water, has not been widely embraced due to its high cost and relatively low removal efficiency [37-39]. Wastewaters containing oil and grease, derived from vegetable oils, with a significant amount of linoleic acid have been reported to be challenging to treat due to the presence and concentration of linoleic, palmitic and myristic acids produced [40]. Wastewaters containing fat and oils were traditionally treated physically, which is currently considered insufficient if the fat is in a dispersed form [41]. Abid Baig et al., [29] studied effectiveness of gravity separation and dissolved air floatation for the removal of oil and grease from industrial and domestic wastewaters and about $85 \%$ removal efficiency was achieved in removal as emulsified oil from the wastewaters.

Microbial degradation of oil wastewater involving the application of variety of microorganisms such as bacteria, molds, and yeasts, which have demonstrated effective degradability of oil-wastewater, has attracted attention in recent time [42-46]. Biological treatment of salad oil and grease from food wastewater by Yarrowia lipolytica W29 has been studied [47]. Similarly, treatment of wastewater containing high concentrations of oil and grease matter with photosynthetic bacteria from food and agricultural wastewater has been reported in the literature [48-50]. Adsorption techniques using various adsorbents such as clay minerals have been successful in removing oil-grease from wastewater streams $[24,51,52]$. The application of membrane separation for the treatment of oily wastewater is demanded due to its high efficiency to handle a low concentration of oil. Though the use of membranes is generally hindered by membrane fouling, its economical advantage has not been that robust [53-56]. However, studies have investigated improvement and modification to obtain less fouling and higher fluxes.

Application of membrane processes using pressure as the driving force for the treatment of oily water have been applied at different locations [57-60]. The membrane technology has been integrated in some existing treatment plants to improve the quality of the treated wastewater in order to meet required limits for oil in discharged wastewaters, though it may be operated independently. Oil and grease treatment process involving aerobic biological process alone or in combination with physicochemical treatment alternatives involves high capital investments, requires skilled work force in addition to being energy intensive. In comparison, anaerobic treatment system involves low investment, omitting aeration equipment, sludge disposal facility, and recirculation and provides biogas as a fuel substitute and therefore, the system is a more viable alternative as a pretreatment facility.

The challenges militating against anaerobic treatment of wastewater containing oil and grease are the adsorption of a thin layer of oil and grease around biomass particles, 
which cause biomass flotation and washout. Acute toxicity of the resulting LCFA, especially unsaturated LCFA, to both methanogens and acetogens, adversely affect the application of anaerobic treatment to wastewater containing oil and grease [28, 61]. In the last few years the development of upflow anaerobic sludge blanket (UASB) concept has improved the anaerobic wastewater treatment technology and hence it wide application [62-64]. Saatci et al., [65] reported about 70\% removal efficiency of total lipids (TL) and fatty acids (FA) from wastewaters of a sunflower oil factory in Turkey using upflow anaerobic sludge blanket (UASB) reactor.

Treatment of wastewaters with high oil and grease content using thermophilic treatment facilitates solubility of these contaminants in the water stream; however, it leads to fall in the sludge settleability as the temperature increases and consequently, washout of biomass and low quality effluent [66-69]. Many studies have attempted to minimize the disadvantages of this process by coupling thermophilic reactor with membrane [70, 71]. Removal efficiency (>90\%) of oil and grease was obtained by Kurian and Nakhla [72] using an aerobic membrane-coupled bioreactor (MBR) operating at mesophilicthermophilic transitional temperatures $\left(40^{\circ} \mathrm{C}\right)$.

\section{CONCLUSION}

Wastewaters containing high concentration of oil and grease are increasing in volume due to the expansion in the oil processing industries worldwide. The has increased the percentage composition of oil and grease in wastewater stream, which in turn caused avert effects on the ecology and the equipment used in the treatment plants. This invariably has identified oil and grease as emerging pollutants of concern (EPC) in wastewater stream and this has opened up research opportunity in the field of wastewater treatment.

\section{ACKNOWLEDGEMENT}

The invaluable suggestions, contributions and corrections of the reviewers and the editor to the IIUM Engineering Journal are humbly appreciated.

\section{REFERENCES}

[1] W.U. Lan, G.E. Gang, and W.A.N. Jinbao, Biodegradation of oil wastewater by free and immobilized Yarrowia lipolytica W29, Journal of Environmental Sciences vol. 21, pp. 237242, 2009.

[2] S. Yacob, Progress and challenges in utilization of palm biomass, Advanced Agriecological Research Sdn. Bhd. http://www.jst.go.jp/asts/asts_j/files/ppt/15_ppt.pdf., December, 2008.

[3] S. Mendiola, J.J. Achutegui, F.J. Sanchez, and M.J. San, Polluting potential wastewater from fish-meal and oil industries. Grasa Aceites , vol. 49, pp. 30-33, 1998.

[4] USEPA, EPA. Method 1664 revision A: N-hexane extractable material (HEM; oil and grease) and silica gel treated N-hexane extractable material (SGT-HEM; non-polar material) by extraction and gravimetry. Washington DC: United States Environmental Protection Agency, 1999.

[5] M.J. Travis, N. Weisbrod,, and A. Gross, Accumulation of oil and grease in soils irrigated with greywater and their potential role in soil water repellency. Science of the Total Environment, vol. 394, pp. 68-74, 2008.

[6] H. E. Tatem, B. A. Cox, and J. W. Anderson, The toxicity of oils and petroleum hydrocarbons to estuarine crustaceans, Estuarine, Coastal and Shelf Science, vol. 6, pp. 365373, 1978.

[7] H. Wake, Oil refineries: A review of their ecological impact on the aquatic environment, Estuarine, Costal and Shelf Science, vol. 62, pp.131-140, 2005. 
[8] K. Hanaki, T. Matsuo, and M. Nagase, Mechanism of inhibition caused by long-chain fatty acids in anaerobic digestion process. Biotechnol. Bioeng., vol. 23, pp.1591-1610, 1981.

[9] E. Salminen, J. Rintala, L.Ya. Lokshina, and V.A. Vavilin, Anaerobic batch degradation of solid poultry slaughterhouse waste. Water Sci. Technol., vol. 41, No.3, pp. 33-41, 2000.

[10] A.-I. Qatibi, A. Bories, and J.-L. Garcia, Sulfate reduction and anaerobic glycerol degradation by mixed microbial culture. Curr. Microbiol., vol. 22, pp. 47-52, 1991.

[11] H.C. Dubourguier, E. Samain, G. Prensier, and G. Albagnac, Characterization of two strains of Pelobacter carbinolicus isolated from anaerobic digesters. Arch. Microbiol., vol. 145, pp. 248-253, 1986.

[12] F. S. Manning, and H. S. Eric, Assessment Data Base for Petroleum Refining Wastewater and Residues. Washington: U.S. Department of Commerce, NTIS, pp. 94-101, 1983.

[13] B.K. Bala, Studies on biodiesels from transformation of vegetable oils for diesel engines. Energy Edu. Sic Technol., vol. 15, pp.1-43, 2005.

[14] F. Ma, and M.A. Hanna, Biodiesel production: a review. Bioresource Technology, vol. 70, pp.1-15, 1999.

[15] A. Demirbas, and H. Kara, New options for conversion of vegetable oils to alternative fuels Energy Sour Part A Recov. Util. Environ Effects, vol. 28, pp.619-626, 2006.

[16] A. L. Ahmad, S. Bhatia, N. Ibrahim, and S. Sumathi, Adsorption of Residual Oil from Palm Oil Mill Effluent Using Rubber Powder. Brazilian Journal of Chemical Engineering, vol. 22, No.3, pp. 371-379, 2005.

[17] G. B. Techobanglous, and L. Franklin, Wastewater Engineering, 3rd edition, Metcalf and Eddy Inc., 1995.

[18] E. Friedler, Quality of individual domestic greywater streams and its implication for on-site treatment and reuse possibilities. Environ Technol., vol. 25, pp.997-1008, 2004.

[19] G. Vidal, A. Carvalho, R. Mendez, and J.M. Lema, Influence of the content in fats and proteins on the anaerobic biodegradability of dairy wastewaters. Bioresource Technology, vol. 74, pp.231-239, 2000.

[20] M.C. Cammarota, and G.L.S. Annajr, Metabolic blocking of exopolysaccharides synthesis effects on microbial adhesion and biofilm accumulation. Biotechnology Letters, vol. 20, pp.1-4, 1998.

[21] E. El-Bestawy, M. H. El-Masry, and N.E. El-Adl, The potentiality of free Gram-negative bacteria for removing oil and grease from contaminated industrial effluents. World Journal of Microbiology \& Biotechnology, vol. 21, pp.815-822, 2005.

[22] G. T. M. Busca, Doctoral Diss., Treatment of Semi-Synthetic Metalworking Fluids: Membrane Filtration and Bioremediation, University of Nottingham, UK. 2004.

[23] K. Karakulski, W. A. Morawski, and J. Crzechulska, Purification of bilge water by hybrid ultrafiltration and photocatalytic process, Separation and Purification Technology, vol. 14, pp.163-173, 1998.

[24] T. Mohammadi, and A. Esmaelifar, Journal of Membrane Science, vol. 254, pp.129 - 137, 2005.

[25] A.G. Stams, and E.S.J. Oude, Understanding and advancing wastewater treatment. Current Opinion in Biotechnology, vol. 8, pp. 328-334, 1997.

[26] F.A. EL-Gohary, S.I. Aboelella, and H.I. Ali, Management of wastewater from soap and food industries: a case study. Science of the Total Environment, vol. 6, pp. 203-212, 1987.

[27] A.C. Chao, and W. Yang, Biological treatment of wool scouring wastewater. Journal of the Water Pollution Control Federation, vol. 53, No.3, pp. 311-317, 1981.

[28] A. Rinzema, M. Boone, K. van Knippenberg, and G. Lettinga, Bactericidal effect of long chain fatty acids in anaerobic digestion. Water Environ. Res., vol. 66, pp. 40-49, 1994.

[29] M. Abid Baig, M. Mir, Z. I. Bhatti, and M A. Baig, Removal of oil and grease from industrial effluents. EJEAFChe, vol. 2, No 5, pp.577-585, 2003.

[30] APHA, Standard methods for the examination of water and wastewater, 16th Edn. American Public Health Association, New York, 2005.

[31] S. Rintoul, New ASTM Test Method Offers Quick and Easy Oil and Grease Measurement for Water and Soil Samples. Wilks Enterprise, Inc., www.WilksIR.com, pp. 1-3, 2010. 
[32] M. Cheryan, and N. Rajagopalan, Membrane processing of oily streams, wastewater treatment and waste reduction, Journal of Membrane Science, vol. 151, pp.13-28, 1998.

[33] Laws of Malaysia. Environmental Quality Act and Regulations. Malaysia: MDC Publishers Sdn Bhd., 2003.

[34] A.J.K. Chowdhury, M.Z. Alam and S.H. Shahlizah, Isolation, purification and screening of fungal strain fro effective bioconversion of palm oil mill effluent. Proceedings of the 1st International Conference on Natural Resources Engineering \& Technology 2006. Putrajaya, Malaysia, pp.167-75, 2006.

[35] L. K. Wang, Y. T. Hung, H. H. Lo, and C. Yapijakis, (Eds) Handbook of Industrial and Hazardous Wastes Treatment, Second Edition, 2004, Marcel Dekker, New York, 2004.

[36] J. Rubio, M. L. Souza, and R. W. Smith, Overview of flotation as a wastewater treatment technique, Minerals Engineering, vol. 15, pp.139-155, 2002.

[37] K. Karakulski, A. Kozhiwski, and A. W. Morawski, Purification of oily wastewater by ultrafiltration, Separation Technology, vol. 5, pp.197-205, 1995.

[38] Y. C. Song, I. S. Kim, and S. C Koh, Demulsification of oily wastewater through a synergistic effect of ozone and salt, Water Science and Technology, vol. 38, pp.247-253, 1998.

[39] B. Meyssami, and A. B. Kasaeian, Use of coagulants in treatment of olive oil wastewater model solutions by induced air flotation, Bioresource Technology, vol. 96, pp.303-307, 2005.

[40] J.A. Lalman, and D.M. Bagley, Anaerobic degradation and inhibitory effects of linoleic acid. Water Res., vol. 34, No.17, pp4220-4228, 2000.

[41] M.H. El-Masry, E. El-Bestaway, and N.I. El-Adl, Bioremediation of vegetable oil and grease from polluted wastewater using a sand biofilm system. World Journal of Microbiology and Biotechnology, vol. 20, pp551-557, 2004.

[42] T. H. Erguder, E. Guven, and G. N. Demirer, Anaerobic treatment of olive mill wastewaters in batch reactors. Process Biochemistry, vol. 36, No.3, pp.243-248, 2000.

[43] M. Kissi, M. Mountadar, O. Assobhei, E. Gargiulo, G. Palmieri, and P. Giardina, Roles of two white-rot basidiomycete fungi in decolorization and detoxification of olive mill wastewater. Applied Microbiology and Biotechnology, vol. 57, No.1- 2, pp. 221-226, 2001.

[44] K. Ettayebi, F. Errachidi, L. Jamai, A. M. Tahri-Jouti, K. Sendide, and M. Ettayebi, Biodegradation of polyphenols with immobilized Candida tropicalis under metabolic induction FEMS Microbiology Letters, vol. 223, No.2, pp.215-219, 2003.

[45] E. Ammar, M. Nasri, and K. Medhioub, Isolation of phenol degrading Enterobacteria from the wastewater of olive oil extraction process. World Journal of Microbiology and Biotechnology, vol. 21, No.3, pp.253-259, 2005.

[46] A. Dhouib, M. Ellouz, F., Aloui, and S., Sayadi, Effect of bioaugmentation of activated sludge with white rot fungi on olive mill wastewater detoxification. Letters in Applied Microbiology, vol. 42, No.4 pp.405-411, 2006.

[47] L. Wu, Y. P. Luo, J. B. Wan, and S. G. Li, Use of Yarrowia lipolytica for the treatment of oil/grease wastewater. Research of Environmental Science (China), vol. 19, No.5, pp 122$125,2006$.

[48] K. Sasaki, N. Noparatnaraporn, and S. Nagai, Use of photosynthetic bacteria for the production of SCP and chemicals from organic wastes, In Bioconversion of Waste Materials to Industrial Products. Ed. A.M. Martin. Elsevier Applied Science Publishers, New York, London, Tokyo, pp. 223-262, 1991.

[49] M.A. Hassan, Y. Shirai, N. Kusubayashi, M.I.A. Karim, K. Nakanishi, and K. Hashimoto, The production of polyhydroxyalkanoate from anaerobically treated palm oil mill effluent by Rhodobacter sphaeroides. Journal of Bioscience and Bioengineering, vol. 83, pp.485-488, 1997.

[50] K. Takeno, Y. Yamaoka, and K. Sasaki, Treatment of oil-containing sewage wastewater using immobilized photosynthetic Bacteria. World Journal of Microbiology \& Biotechnology, vol. 21, pp.1385-1391, 2005.

[51] K. Almalah, M.O.J. Azzam, and N.I. Abu-Lail, Separation and Purification Technology, vol. 20, pp. $225-234,2000$. 
[52] B. Tryba, A.W. Morawski, R.J. Kalenczuk, and M., Inagak, Spill Science of Technology Bulletin, vol. 8, No.5-6, pp.569-571, 2003.

[53] U. Daiminger, W. Nitsch, P. Plucinski, and S. Hoffmann, Novel techniques for oil/water separation, Journal of Membrane Science, vol. 99, pp.197-203, 1995.

[54] J. Kong, and K. Li, Oil removal from oil-in-water emulsions using PVDF membranes. Sep. Purif. Technol., vol. 16, pp.83-93, 1999.

[55] M., Gryta, K. Karakulski, and A. W. Morawski, Purification of Oily Wastewater by Hybrid UF/MD, Water Res., vol. 35, No.17, pp. 3665-3669, 2001.

[56] T.-H. Bae, S.-S. Han and T.-M. Tak, Membrane sequencing batch reactor system for the treatment of dairy industry wastewater. Process Biochem. Vol. 39, pp. 221-231, 2003.

[57] S.B. Lee, Y. Aurelle, and H. Roques, Concentration polarization, membrane fouling and cleaning in ultrafiltration of soluble oil. J. Membrane Sci., vol. 19, No1, pp. 23-38, 1984.

[58] M. Nyström, Ultrafiltration of $\mathrm{O} / \mathrm{W}$ emulsions stabilized by limiting amounts of tall oil, Colloids and Surfaces, vol. 57, pp. 99-114, 1991.

[59] B. Tansel, J. Regula, and R. Shalewitz, Treatment of fuel oil and crude oil contaminated waters by ultrafiltration membranes, Desalination, vol. 102, pp.301-311, 1995.

[60] S. Panpanit, and C. Visvanathan, The role of bentonite addition in UF flux enhancement mechanisms for oil/water emulsion, Journal of Membrane Science, vol. 184, pp.59-68, 2001.

[61] I. Angelidaki, and B.K. Ahring, Effect of free long-chain fatty acids on thermophilic anaerobic digestion. Appl. Microbiol. Biotechnol. vol. 37, pp. 808-812, 1992.

[62] L. Hulshof Pol, H. Euler, A. Eitner, and D. and Grohganz, GTZ Sectoral project, promotion of anaerobic technology for the treatment of municipal and industrial sewage and waste. In: Proc. 8th International Conference on Anaerobic Digestion, Sendai, Japan, vol. 2. pp.282285, 1997.

[63] L.H.A. Habets, A.J.H.H. Engelaar, and N. Groeneveld, Anaerobic treatment of inuline effluent in an internal circulation reactor. Water Sci. Technol., vol. 35, No10, pp.189-197, 1997.

[64] M.M. Alves, J.A. Mota Vieira, R.M. Alvares Pereira, M.A. Pereira, and M. Mota, Effect of lipids and oleic acid on biomass development in anaerobic fixed-bed reactors. Part I: Biofilm growth and activity. Water Res., vol. 35, No.1, pp.255-263, 2001.

[65] Y. Saatci, E.I. Arslan, and V. Konar, Removal of total lipids and fatty acids from sunflower oilfactory effluent by UASB reactor Bioresource Technology, vol. 87, pp.269-272, 2003.

[66] F.D. Çetin, and G. Sürücü, Effects of temperature and $\mathrm{pH}$ on the settlability of activated sludge flocs. Water Sci. Technol., vol. 22, No.9, pp. 249-254, 1990.

[67] T.A. Barr, J.M.Taylor, and S.J.B. Duff, Effect of HRT, SRT and temperature on the performance of activated sludge reactors treating bleached kraft mill effluent. Water Res., vol. 30, No.4, pp. 799-810, 1996.

[68] C. S. Tripathi, and A. D. Grant, Comparison of mesophilic and thermophilic aerobic biological treatment in sequencing batch reactors treating bleached kraft pulp mill effluent. Water Res., vol. 33, No.3, pp.836-846, 1999.

[69] T.M. Lapara, and J. E. Alleman, Thermophilic aerobic wastewater treatment. Water Res., vol.33, No.4, pp. 895- 908, 1999.

[70] J. Lopetegui, and L. Sancho, Aerated thermophilic biological treatment with membrane ultrafilteration: alternative to conventional technologies treating paper mill effluents. Water Sci. Technol.: Water Supply, vol. 3, No. 5-6, pp245-252, 2003.

[71] C. G. Klatt, and T. M. LaPara, Aerobic biological treatment of synthetic municipal wastewater in membrane-coupled bioreactors, Biotechnology and Bioengineering, Vol. 82, No.3, pp. 313-319, 2003.

[72] R. Kurian, and G. Nakhla, Performance of Aerobic MBR Treating High Strength Oily Wastewater at Mesophilic -Thermophilic Transitional Temperatures. Water Environment Foundation, Ontario Canada, 2006 